DOI https://doi.org/10.30525/978-9934-26-074-2-10

\title{
ВЗАСМОДІЯ ОРГАНІВ ДЕРЖАВНОЇ ВЛАДИ УКРАЇНИ ТА ОРГАНІВ МІСЦЕВОГО САМОВРЯДУВАННЯ В УМОВАХ МУНІЦИПАЛЬНОЇ РЕФОРМИ
}

\author{
Камардіна Ю. В. \\ кандидат юридичних наук, \\ дочент кафедри права та публічного адміністрування \\ Маріупольського державного університету \\ м. Маріуполь, Донецька область, Украӥна
}

Розвиток будь-якого суспільства багато в чому визначається системою багаторівневого управління, від центрального до місцевого. Налагоджений механізм взаємодії і розподілу повноважень - основа стабільності будь-якої держави. Місцеве самоврядування в Україні пройшло складний і суперечливий шлях розвитку. На сьогоднішній день, в умовах здійснення реформ різних сфер суспільного і державного життя місцеве самоврядування відіграє особливу роль в реалізації публічної влади. Становлення місцевого самоврядування та системи органів державного управління $\epsilon$ визначальним в процесах формування в Україні правової держави і демократичного суспільства. Місцеве самоврядування являє собою процес реалізації муніципальної влади, що є найбільш наближеним безпосередньо до населення рівнем публічної влади, яка забезпечує більш повний об'єм інтересів територіальної громади.

Конституцією України 1996 року [1] було визнано та гарантовано місцеве самоврядування. Місцеве самоврядування і державна влада в Україні тісно взаємопов'язані, оскільки у них єдине джерело - народ. У місцевого самоврядування $\epsilon$ свої певні функції, власні повноваження, окреслені Конституцією України [1] і базовим законом про місцеве самоврядування [2]. Це, в свою чергу передбачає наявність особливого механізму взаємодії органів місцевого самоврядування 3 органами державної влади, при якому відсутня безпосередня адміністративна залежність між ними, але є окреслені законом повноваження, форми i методи такої взаємодії.

Місцеве самоврядування являє собою цілісну систему суспільних відносин, пов'язану з територіальною самоорганізацією населення, яка передбачає самостійне вирішення населенням питань життєзабезпечення територіальної громади, устроєм та функціонуванням муніципальної влади відповідно до наділених законом власними повноваженнями $\mathrm{i}$ 
окремими державними повноваженнями. Воно є складовою частиною механізму публічної влади. Для успішного функціонування цього механізму необхідне відповідне нормативно-правове регулювання суспільних відносин, певна самостійність місцевого самоврядування, вибудовування певної владної вертикалі.

Як відзначають Л. В. Бондарчук та В. А. Урбанович «в системі органів місцевого самоврядування відбувається поєднання державних та самоврядних повноважень, громадсько-територіальних та державних інтересів» [3, с. 5]. Взаємодія органів державної влади та місцевого самоврядування має на увазі, що вони як партнери, тобто, рівні по відношенню до головного об'єкта управління, і воно здійснюється заради досягнення спільної мети - підвищення рівня і якості життя населення кожної територіальної громади. Поле взаємодії державної влади i місцевого самоврядування дуже широке. Воно охоплюе спільну діяльність $з$ формування органів місцевого самоврядування та створенню умов для реалізації ними своїх конституційних повноважень; включає весь комплекс питань, пов'язаних 3 участю органів місцевого самоврядування поряд 3 державними органами влади в реалізації загальнодержавної політики в галузі охорони здоров'я, освіти, культури, екології, в соціальній сфері і багатьох інших.

Розпочата в 2014 році реформа місцевого самоврядування [4] призвела до суттєвих змін у відносинах муніципальних і державних органів влади. Сьогодні потрібно дати оцінку процесу реформування місцевого самоврядування, визначити напрямки оптимізації взаємодії державної і муніципальної влади і шляхи подолання недоліків як в законодавстві, так і в реальній практиці.

Муніципальна реформа, у першу чергу, пов'язана 3 необхідністю забезпечення автономії місцевого самоврядування і разом з тим єдності рівнів публічної влади. Ступінь децентралізації влади визначається об’єктивними потребами розвитку всього суспільства, тому на місцевий рівень повинен бути переданий той необхідний обсяг повноважень, який забезпечить максимально ефективне рішення місцевих питань і питань, державного значення, переданих на місцевий рівень. Децентралізація влади призведе до можливості вирішувати питання місцевого значення самим населенням і органами місцевого самоврядування. У зв'язку 3 цим, виникає необхідність у вирішенні протиріччя між існуючими конституційними принципами взаємодії органів державної влади і органів місцевого самоврядування, 3 одного боку, і практикою їх здійснення, 3 іншого.

Аналіз взаємин між органами державної влади та місцевого самоврядування грунтується на двох базових характеристиках: автономії 
місцевого самоврядування i інтеграції місцевого самоврядування. Під автономією місцевого самоврядування розуміється можливість органів місцевого самоврядування діяти i виконувати свої функції без підпорядкування іншим (державним) органам влади. Основним індикатором місцевої автономії $€$ самостійне розпорядження ресурсами i захист від контролю вищих органів влади. А інтеграція місцевого самоврядування являє собою механізм включення органів місцевого самоврядування в загальну систему управління державою. Рівень інтеграції місцевого самоврядування залежить від обсягу державних повноважень, переданих органам місцевого самоврядування, i від ступеня їх участі в реалізації загальнодержавної політики.

У взаємодії державної влади і місцевого самоврядування можна виділити дві сторони - соціально-економічну та політико-правову.

Соціально-економічна сторона взаємодії визначається податковою та бюджетною політикою держави, можливістю органів місцевого самоврядування самостійно мобілізувати і використовувати економічні ресурси для виконання своїх функцій, а також ступенем фінансової залежності від держави і підконтрольності в розпорядженні ресурсами. Політико-правова сторона включає в себе правовий елемент інституційне регулювання місцевого самоврядування та його відносин 3 органами державної влади (те, що закріплюється в законодавстві і визначає принципи формування та обсяг повноважень органів місцевого самоврядування, порядок делегування їм державних повноважень, можливості втручання державної влади в їх діяльність і т.д.) і політичну складову - реальну практику взаємодії між органами місцевого самоврядування та державної влади.

Підтримка місцевого самоврядування з боку держави і створення умов для сталого самостійного розвитку територіальних громад повинні бути орієнтовані на ефективне i узгоджене функціонування органів державної влади і органів місцевого самоврядування 3 метою забезпечення конституційних прав і свобод громадян України, підвищення життєвого рівня та добробуту кожного мешканця територіальної громади.

Без постійної підтримки з боку держави територіальні громади, в силу об'єктивних причин, не можуть ефективно брати участь в проведенні реформ, в зміцненні державності, в задоволенні основних життєвих потреб населення, що проживає на ії території, тим більше, що державна підтримка розвитку місцевого самоврядування є законодавчо встановленим обов'язком органів державної влади. Тому необхідне здійснення заходів, що забезпечують поглиблення реформи місцевого самоврядування, планомірний перехід від підтримки державою становлення влади на базовому рівні до підтримки соціально-еконо- 
мічного розвитку територіальних громад, реалізації в повному обсязі конституційних повноважень місцевого самоврядування.

При цьому однією з найважливіших завдань муніципальної реформи $\epsilon$ встановлення системи «стримувань і противаг» між різними рівнями влади, що забезпечують гарантії місцевого самоврядування, в тому числі гарантії держави щодо процесу здійснення місцевого самоврядування. На це вказує Концепція реформування місцевого самоврядування та територіальної організації влади 2014 року [4], реалізація якої сприяти «забезпеченню розподілу повноважень між органами місцевого самоврядування базового та регіонального рівня, місцевими держадміністраціями та територіальними органами центральних органів виконавчої влади». Тільки це може забезпечити і гарантувати ефективну і безперешкодну взаємодію державної влади і місцевої влади.

Поки що ведеться пошук форм і механізмів ефективної взаємодії державної влади і місцевої влади, але ці форми і механізми будуть удосконалюватися і розвиватися, так як державний і місцевий рівень $\epsilon$ союзниками в багатьох питаннях i контакт 3 органами місцевого самоврядування дуже важливий для органів державної влади, включаючи всі ії гілки.

Таким чином, якщо широко дивитися на позначену проблему взаємодії держави і місцевого самоврядування, то можна трактувати органи державного управління і органи місцевого самоврядування як елементи єдиної системи соціального управління, публічної влади, що забезпечує життєдіяльність суспільства як єдиного цілого.

\section{Література:}

1. Конституція України від 28 червня 1996 року. URL: http://zakon.rada.gov.ua/ go/254к/96-вр (дата звернення: 30.03.2021).

2. Про місцеве самоврядування в Україні: Закон України від 21.05.1997 p. № 280/97-ВР. Дата оновлення: 20.10.2019. URL: https://zakon.rada.gov.ua/laws/show/280/97-\%D0\%B2\%D1\%80 (дата звернення: 30.03.2021).

3. Бондарчук Л. В., Урбанович В. А. Взаємодія органів державної влади та органів місцевого самоврядування: правові й функціональні аспекти. Журнал Науковий огляд. 2015. № 11 (21). С. 1-9. URL: https://core.ac.uk/download/pdf/217450142.pdf (дата звернення: 30.03.2021).

4. Концепція реформування місцевого самоврядування та територіальної організації влади в Україні: схвалено розпорядженням Кабінету Міністрів України від 01.04.2014 р. № 333-рп. Офіційний вісник України. 2014. № 30. Ст. 831. 